unreasonable for our children. Similar methods were used in adults with type I diabetes and showed that an enhanced metabolic response to adrenaline-that is, a significant increase in plasma concentrations of glycerol, free fatty acids, lactate, and glucose and in the rate of glucose production - also occurs after glycaemia has been normalised using a clamp. ${ }^{10}$ These data also suggest that hyperglycaemia does not affect the sensitivity to adrenaline and support our idea that our results cannot be explained as being simply the result of a lack of insulin. ${ }^{910}$ Glycaemic control therefore might not mean metabolic control, which is against the current clinical view. This might be explained by the idea that the whole picture of metabolic events observed in type I as well as type II diabetes results from different metabolic lesions within the metabolism of glucose, lipids, and amino acids. With regard to the dose-response curves of insulin lipid oxidation, hepatic glucose production, carbohydrate oxidation, glucose storage, and amino acid oxidation all show different insulin sensitivities - that is, half maximal effects are observed at plasma insulin concentrations ranging between 29 and $213 \mathrm{mU} / 1 .{ }^{19-21}$ These data suggest that a given plasma insulin concentration may be sufficient to normalise blood glucose concentrations but protein turnover, for instance, may still be disturbed. To achieve optimal metabolic (instead of glycaemic) control in diabetic patients the need to study variables other than plasma glucose concentration is obvious.

We conclude that our observations may have important clinical implications for patients with type I diabetes mellitus. Such patients are commonly prone to tissue catabolism which is obvious during intercurrent stress-for example, an infection. As an increased metabolic response to adrenaline has also been reported for fasting, ${ }^{22}$ malnutrition, ${ }^{23}$ hyperthyroidism, ${ }^{24}$ and sepsis ${ }^{25}$ an energy deficit due to increased thermogenesis may provide a rationale for tissue wasting during catabolism.

We thank Mrs S Ohlendorf for technical help, Dr A Balks for determining urinary albumin concentrations, and Mrs M Bürger for helping to prepare the manuscript. This work was presented in part at the 23rd annual meeting of the Deutsche Diabetes-Gesellschaft in Tübingen in May 1988 and contains part of MD's doctoral thesis. This work was supported by a grant from Braun Melsungen, Melsungen, Federal Republic of Germany.

1 Garrow JS. Energy balance in man-an overview. Am $\mathcal{f}$ Clin Nutr 1987;45: $114-9$

\title{
Changing belief in iridology after an empirical study
}

\section{Paul Knipschild}

Department of

Epidemiology and Health

Care Research,

University of Limburg, PO

Box 616, 6200 MD

Maastricht, The

Netherlands

Paul Knipschild, MD,

professor of epidemiology

BrMed J 1989;299:491-2
2 Sims EAH, Danforth E Jr. Expenditure and storage of energy in man. $f$ Clin Invest 1987;79:1019-25.

3 DeFronzo RA, Simonson D, Ferranninni E. Hepatic and peripheral insulin resistance: a common feature of type 2 (non-insulin-dependent) and type 1
(insulin-dependent) diabetes mellitus. Diabetologia 1982;23:313-9.

4 Proietto J, Nankervis A, Aitken P, Caruso G, Alford F. Glucose utilization in type 1 (insulin-dependent) diabetes: evidence for a defect not reversible by acute elevations of insulin. Diabetologia 1983;25:331-5.

5 Yki-Järvinen H, Koivisto VA. Natural course of insulin resistance in type 1 diabetes. $N$ Engl f Med 1986;315:224-30

6 Nair KS, Halliday D, Garrow JS. Increased energy expenditure in poorly controlled type 1 (insulin-dependent) diabetic patients. Diabetologia 1984;27:13-6.

7 Home PD, Capaldo B, Burin JM, Worth R, Alberti KGMM. A crossover comparison of continuous subcutaneous insulin infusion (CSII) agains multiple injections in insulin-dependent diabetic subjects. Improved contro with CSII. Diabetes Care 1982;5:457-65.

8 Leslie P, Jung RT, Isles TE, Baty J, Newton RW, Illingworth P. Effect of optimal glycaemic control with continuous subcutaneous insulin infusion on energy expenditure in type I diabetes mellitus. Br Med F 1986;293:1121-6.

9 Shamoon H, Hendler R, Sherwin RS. Altered responsiveness to cortisol, epinephrine, and glucagon in insulin-infused juvenile onset diabetics. epinephrine, and glucagen
Diabetes 1980;29:284-91.

10 Hilsted J, Richter E, Madsbad S, et al. Metabolic and cardiovascular responses to epinephrine in diabetic autonomic neuropathy. $N$ Engl f Med 1987;317 $421-6$

11 Kahn J, Sisson JC, Vinik AI. QT interval prolongation and sudden cardiac death in diabetic autonomic neuropathy. $\mathcal{F}$ Clin Endocrinol Metab 1987;64 751-4.

12 Lukaski HC, Johnson PE, Bolonchuk WW, Lykken GI. Assessment of fat fre mass using bioelectrical impedance measurements of the human body. Am f Clin Nutr 1985;41:810-7.

13 Müller MJ, Acheson KJ, Jequier E, Burger AG. Effect of thyroid hormones on oxidative and nonoxidative glucose metabolism in humans. Am $\mathcal{f}$ Physiol 1988;255: E146-52.

14 Müller MJ, Burger AG, Ferranninni E, Jequier E, Acheson KJ. Glucoregulatory function of thyroid hormones: role of pancreatic hormones. Am f Physiol 1989;259: E101-10.

15 Müller MJ, Paschen U, Seitz HJ. Effect of ketone bodies on glucose production and utilization in the miniature pig. $\mathcal{F}$ Clin Invest 1984;74: production $249-61$.

16 Abu Khaled M, McCutcheon MJ, Reddy S, Pearman PL, Hunter GR, Weinsier RL. Electrical impedance in assessing human body composition: the BIA method. Am f Clin Nutr 1988;47:789-92.

17 Kitamara K, Jorgensen CR, Gobel L, Taylor H, Wang Y. Hemodynami correlates of myocardial oxygen consumption during upright exercise. J Appl Physiol 1972;32:516-22

18 Huszar G, Koivisto V, Davis E, Felig P. Urinary methylhistidine excretion in juvenile-onset diabetics: evidence of increased protein catabolism in the absence of ketoacidosis. Metabolism 1982;31:188-91.

19 Rizza RA, Mandarino LJ, Gerich JE. Dose-response characteristics for effects of insulin on production and utilization of glucose. Am F Physiol 1981;240: E630-9.

20 Fukagawa NK, Minaker KL, Rose JW, et al. Insulin-mediated reduction of whole body protein breakdown: dose-response effects on leucine of whole body protein breakdown: dose-response effects on

21 Young AA, Bogardus C, Stone K, Mott DM. Insulin response of components of whole-body and muscle carbohydrate metabolism in humans. Am f Physiol 1988;254:E231-6.

22 Jensen MD, Haymond MW, Gerich JE, Cryer PE, Miles JM. Lipolysis during fasting. Decreased suppression by insulin and increased stimulation by epinephrine. I Clin Invest 1987;79:207-13.

23 Jayarajan MP, Shetty PS. Cardiovascular $\beta$-adrenoreceptor sensitivity in undernourished subjects. Br F Nutr 1987;58:5-11

24 Gelfand RA, Hutenson-Williams KA, Bode AA, Castellino R, Sherwin RS Catabolic effects of thyroid hormone excess. The contribution of adrenergic activity to hypermetabolism and protein breakdown. Metabolism 1987;36:562-9.

25 Forse RA, Leibel R, Ashkanazy J, Hirsch J, Kinney MJ. Adrenergic control of adipocyte lipolysis in trauma and sepsis. Ann Surg 1987;206:744-51.

(Accepted 16 May 1989)

\section{Subjects, methods, and results}

I performed the inquiry among the first authors of recent papers in the BMF, the fournal of the Royal College of General Practitioners, and three journals of alternative medicine (British Fournal of Homoeopathy, Allgemeine Homöopathische Zeitung, and Acupuncture and Electro-therapeutics Research). In all, 100, 40, and 60 authors respectively were invited to state their belief in iridology by indicating, as a percentage, their belief in the hypothesis that "for certain diseases iridology is a useful diagnostic aid" on a visual analogue scale three weeks before the paper on iridology was published. ${ }^{1} \mathrm{To}$ prevent bias I selected only authors who did not know me, and all of the information was gathered by post.

Of the 200 authors contacted, 83 responded. The paper was sent to them with the request to read it carefully and afterwards reassess their belief. Five of them did not reply in spite of two reminders. The response rate was therefore $39 \%(40 \%, 50 \%$, and $30 \%$ for authors of papers in the BMF, $\mathcal{F} R$ Coll Gen Pract, and the journals of alternative medicine respectively).

The figure summarises the data on the 78 respondents. Fifteen authors (10 of papers in the $B M F$, four of papers in $\mathcal{F} R$ Coll Gen Pract, and one of a paper in a journal of alternative medicine) who did not believe in iridology before they read the report (belief $<10 \%$ ) did not change their opinion after reading it. Three 
of the four who believed strongly in iridology initially (belief $>90 \%$ ) also did not change their opinion. Most respondents, however, were less decided before they read the report. Thirty eight (20 of papers in the $B M \mathcal{F}, 11$ of papers in $\mathcal{F} R$ Coll Gen Pract, and seven of papers in the journals of alternative medicine) were uncertain (belief $40-60 \%$ ) before reading the report, but two thirds of these (14, nine, and three respectively) did not believe in iridology (belief $<10 \%$ ) after reading it.

Four authors indicated that their belief before reading the report was $0 \%$ and one that his belief after reading it was $100 \%$. The paper's impact on the 73 other authors was expressed as a likelihood ratio, which was calculated by dividing the odds of belief after reading the report by that before reading it. For example, if a reader's belief changed from $60 \%$ to $10 \%$ the likelihood ratio $=(0 \cdot 1 / 0 \cdot 9) /(0 \cdot 6 / 0 \cdot 4)=0 \cdot 07$. The median likelihood ratio was $0 \cdot 07$, with the second quartile $=0.03$ and the fourth quartile $=0 \cdot 28$. The curved lines in the figure that represent these likelihood ratios fitted reasonably well with the data, especially at beliefs below $60 \%$ before the report was read. The median likelihood ratios for authors of papers in the BMF, $\mathcal{F} R$ Coll Gen Pract, and the journals of alternative medicine were $0 \cdot 06,0 \cdot 06$, and $0 \cdot 17$ respectively.

\section{Comment}

I restricted the inquiry to authors in medical journals as they may be better able to judge empirical evidence. The respondents' beliefs and their propensities to change them may have been different from those of the authors who did not respond. Regression to the mean was not a problem, especially among the authors who reported a previous belief in iridology of about $50 \%$ :

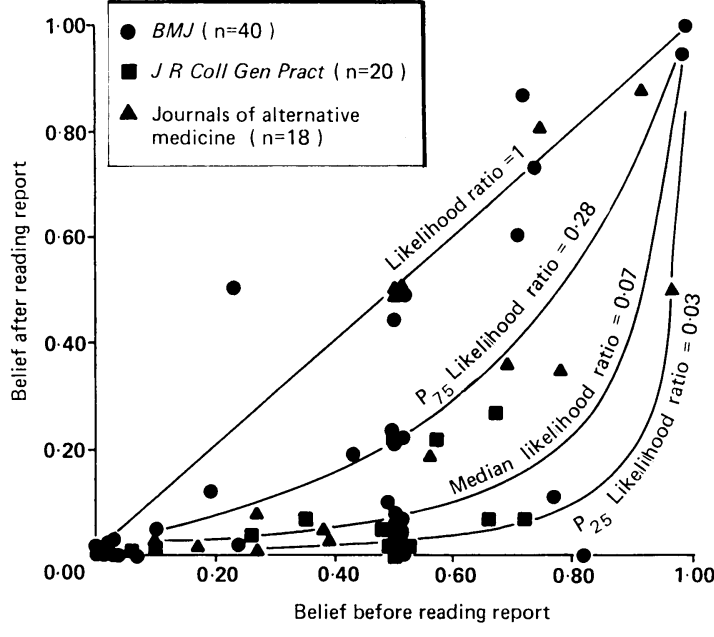

Belief in iridology as a diagnostic aid among 78 authors of papers in "BMF," "F $R$ Coll Gen Pract," and three journals of alternative medicine before and after reading a report that gave empirical evidence against its validity. Curved lines indicate median, second quartile $\left(P_{25}\right)$ and fourth quartile $\left(P_{75}\right)$ likelihood ratios

their change to strong disbelief was impressive. Participation was lowest among doctors of alternative medicine. The report's impact on such doctors was large but less pronounced than that on other doctors (likelihood ratio closer to one). In general the likelihood ratio seemed to describe the results reasonably; its usefulness for measuring the longer term impact of a publication needs further study.

1 Knipschild P. Looking for gallhladder disease in the patient's iris. Br. Hed $1988 ; 297: 1578-81$

Accepted 16. May 1989,

\section{Aflatoxins and heroin}

\section{R G Hendrickse, S M Maxwell, R Young}

Department of Tropical

Paediatrics and

International Child Health,

School of Tropical

Medicine, Liverpool L3

5QA

R G Hendrickse, FRCP,

professor

S M Maxwell, PHD, research

assistant

$\mathrm{R}$ Young, senior technician

Correspondence to Professor Hendrickse.

BrMed f 1989;299:492-3

\section{Subjects, methods, and results}

Aflatoxins are oncogenic and immunosuppressive.' In Africa, where many children are exposed to aflatoxins, ${ }^{23}$ infection with HIV seems to be more prevalent and aggressive than might be predicted. In Britain users of intravenous heroin are prone to infection, particularly with hepatitis B virus and HIV, which seem peculiarly aggressive in these drug abusers. Heroin is produced in subtropical countries from plants and may be susceptible to contamination by aflatoxins. We investigated whether aflatoxins play a part in the pathogenesis of disease in heroin abusers.

The Merseyside drug squad supplied 13 samples of heroin that had been seized. These were analysed for aflatoxins. Urine samples were collected from 133 heroin abusers who were attending clinics in Amsterdam (60), Merseyside (61), and London (12); the samples were rendered anonymous. Urine specimens were also obtained from 99 male volunteers of a similar age (17-40) in Merseyside, who served as controls. All samples were extracted in chloroform and passed through a silica column. ${ }^{4}$ Duplicate samples of heroin were extracted by the method of Haladay and Lansden. Aflatoxin concentrations were determined by high performance liquid chromatography with detection of fluorescence.
Four of the 13 samples of heroin tested contained aflatoxin $B_{1}$ (in concentrations of $1 \cdot 63,4 \cdot 31,5 \cdot 23$, $30.82 \mathrm{nmol} / \mathrm{kg})$. Aflatoxins were detected in $27(20 \%)$ of the 133 urine specimens from the drug users and were more common in the specimens from Amsterdam (19/60) than from Merseyside (8/61). No specimen from London contained aflatoxins. Two of the 99 control urine specimens contained aflatoxins. The table shows the aflatoxins that were detected and their concentrations.

Results of analysis of urine for aftatoxins in heroin addicts and normal controls

\begin{tabular}{|c|c|c|c|}
\hline Subjects & No tested & $\begin{array}{l}\text { No }(\%) \\
\text { positive }\end{array}$ & $\begin{array}{l}\text { Aflatoxins detected } \\
(\mathrm{nmol} / \mathrm{l})\end{array}$ \\
\hline Heroin addicts & 133 & $27(20)$ & \\
\hline Amsterdam & 60 & $19(32)$ & $\begin{array}{l}\mathrm{B}_{1}, 8 \text { patients }(2 \cdot 02-25 \cdot 80) \\
\mathrm{M}_{1}, 6 \text { patients }(1 \cdot 03-29 \cdot 09) \\
\mathrm{M}_{2}, 6 \text { patients }(0 \cdot 4-1 \cdot 88) \\
\mathrm{B}_{2}, 2 \text { patients }(0 \cdot 09,0 \cdot 13) \\
\text { Aflatoxicol, } 1 \text { patient }(0 \cdot 32)\end{array}$ \\
\hline Merseyside & 61 & $8(13)$ & $\begin{array}{l}\mathrm{B}_{1}, 1 \text { patient }(0 \cdot 73) \\
\mathrm{M}_{1}, 6 \text { patients }(0 \cdot 12-1 \cdot 46) \\
\mathrm{B}_{2}, 6 \text { patients }(0 \cdot 13-1 \cdot 53)\end{array}$ \\
\hline $\begin{array}{l}\text { London } \\
\text { Controls }\end{array}$ & 12 & $2(2)$ & $\mathrm{B}_{2}, 2$ controls $(0 \cdot 13-0 \cdot 24)$ \\
\hline
\end{tabular}

\section{Comment}

These results show that a hitherto unsuspected group of people are exposed to aflatoxins, which are injected intravenously. An important difference between this kind of exposure and that from contaminated food is that after absorption from the gut some or all of the aflatoxin in food is detoxified by the liver. Intravenous heroin users thus risk direct systemic exposure 